\title{
ВПЛИВ ПСИХОФІЗІОЛОГІЧНИХ ОСОБЛИВОСТЕЙ СТУДЕНТІВ НА ЗАСВОСННЯ ПРАКТИЧНИХ НАВИЧОК ІЗ НОРМАЛЬНОЇ ФІЗІОЛОГІЇ
}

ДВНЗ «Тернопільський державний медичний університет імені І.Я. Горбачевського МОЗ України», м. Тернопіль

Резюме. У роботі показані особливості засвоєння практичних навичок студентами з нормальної фізіології залежно від психофізіологічних станів. Встановлено, що повноцінне засвоєння практичних навичок із нормальної фізіології залежить від домінування лівої або

Вступ. Сучасний розвиток медичної освіти в Україні, етапи його формування, питання, пов'язані 3 підвищенням якості освіти випускників вищих навчальних медичних закладів, вимагають нових підходів до організації та проведення навчального процесу. Важливою складовою в системі якісної підготовки майбутніх лікарів $є$ не тільки повноцінне забезпечення студентів сучасними підручниками, посібниками, необхідними унаочненнями, а й нові підходи до викладання навчальних дисциплін, пошуки механізмів підвищення якості медичної освіти. Відомо, що вища медична освіта - це системний результат, створений працею чисельних розробників навчальних і робочих програм, планів, які тісно пов'язані з працею авторів підручників, навчальних посібників, із працею самих студентів та викладачів, які читають лекції, проводять практичні та семінарські заняття. Якість підготовки майбутніх лікарів залежить від умов навчання, мотивації студентів, їх психофізіології, фахового рівня професорсько-викладацького складу, матеріально-технічної бази тощо.

У підготовці висококваліфікованого спеціаліста важлива роль відводиться засвоєнню та оволодінню цілого ряду практичних навичок, які пов'язані із запитами клініки і допомагають повноцінно виконувати алгоритм різних лікарських маніпуляцій. Нормальна фізіологія $\epsilon$ важливим навчальним предметом у системі вищої медичної освіти. Вивчаючи даний предмет, студент повинен засвоїти цілий ряд практичних навичок, необхідних у роботі лікаря. Варто зазначити, що якісне освоєння практичних навичок також розширює кругозір лікаря, досконале опанування ними сприяє своєчасному і грамотному наданню невідкладної допомоги хворим. Відомо також, що адекватне засвоєння практичних навичок інтенсифікує вивчення та засвоєння навчального матеріалу, стимулює цікавість до предмета і активізує мислення. Досягнення максимального ефекту при вивченні медичних дисциплін можливе тоді, коли студенти не тільки отримують глибокі теоретичні знання, але й повноцінно освоюють та вдосконалюють практичні навички $[1,2,5]$.

Мета дослідження. Вивчити особливості засвоєння практичних навичок із нормальної фізіології залежно від психофізіологічних особливостей студентів. правої півкуль головного мозку, що вимагає індивідуальних підходів при їх освоєнні та виконанні.

Ключові слова: практичні навички, психофізіологія, нормальна фізіологія.

Матеріал і методи. Для оцінки ефективності засвоєння практичних навичок із нормальної фізіології проведений педагогічний експеримент у 19 академічних групах студентів. Останні в кількості 229 осіб були розподілені на дві групи. До 1-ї групи увійшли праворукі студенти («правші»), до 2-ї - студенти, в яких домінуючою була ліва рука («лівші»). При визначенні праворукості або ліворукості використаний Луганський сенсибілізований опитувальник для визначення ліворукості в дітей $[9,11]$. Серед обстежених студентів праворуких виявилося 195, що становило 85,2 \%, а ліворуких - 34 (14,8 \%). Необхідно зазначити, що майже на аналогічну розповсюдженість ліворуких та праворуких осіб вказують інші дослідники $[6,9,11]$.

Для оцінювання використано ряд практичних навичок із фізіології системи крові. При цьому оцінювалася якість засвоєння наступних практичних навичок:

1. Підрахунок еритроцитів у камері Горяєва.

2. Визначення гемоглобіну за допомогою гемометра Салі.

3. Визначення гематокритного показника.

4. Визначення швидкості осідання еритроцитів.

5. Підрахунок загальної кількості лейкоцитів.

6. Підрахунок лейкоцитарної формули.

7. Визначення ядерного зсуву нейтрофілів.

8. Підрахунок кількості тромбоцитів.

9. Загальний аналіз крові.

Оцінювання якості виконання наведених вище практичних навичок проводилося за 12бальною системою. Варто зазначити, що при аналізі оцінок, отриманих студентами при здачі вказаних вище практичних навичок, враховували питому вагу відмінних, добрих, задовільних та незадовільних оцінок, тривалість виконання практичної навички, а також результати анонімного анкетування студентів. Кількісні величини оброблялися статистично. Різниця між порівнювальними показниками визначалася за критеріями Стьюдента та Манна-Уітні.

Результати дослідження та їх обговорення. Результати успішності студентів, виявлені при виконанні практичних навичок із нормальної фізіології, показані в таблиці. 
Таблиця

Успішність студентів при виконанні практичних навичок із нормальної фізіології (M \pm m)

\begin{tabular}{|c|c|c|}
\hline № п/п & Група студентів & Успішність, бали \\
\hline 1. & $\begin{array}{c}\text { 1-ша (" правші“) } \\
\mathrm{N}=195\end{array}$ & $7,15 \pm 0,12$ \\
\hline 2. & $\begin{array}{c}2 \text {-га (“" лівші“) } \\
\mathrm{N}=34\end{array}$ & $6,20 \pm 0,09$ *** \\
\hline
\end{tabular}

Примітка. $* * *$ - $<<0,001$ порівняно 3 1-ю групою

Встановлено, що середній бал при оцінюванні виконання перерахованих вище практичних навичок у праворуких студентів дорівнював $7,15 \pm 0,12$, а в ліворуких він був меншим і досягав $6,20 \pm 0,09$ бала. Варто зазначити, що наведені цифрові величини статистично достовірно $(\mathrm{p}<0,010)$ відрізнялися між собою. При цьому останній показник виявився меншим, ніж попередній на 13,3 \%. Визначено, що відсоток відмінних оцінок у студентів із домінуючою правою рукою досягав $29,7 \%$, а в осіб із домінуванням лівої руки - 17,6 \%, добрих оцінок відповідно виявилося у 38,9 і $32,3 \%$, задовільних - у 21,0 i 26,4 \%, незадовільних - у 10,4 і 23,7 \%. Наведені величини стверджують, що студенти 3 домінуючою правою рукою краще засвоювали та виконували практичні навички порівняно з ліворукими. Наведене підтверджувалося також якісною успішністю, яка в студентів із домінуючою правою рукою дорівнювала $68,6 \pm 0,6 \%$, а в ліворуких $41,3 \pm 0,6 \%$. Необхідно вказати, що між цими цифровими величинами виявлена статистично достовірна ( $<<0,001)$ різниця.

Установлено також, що ліворукі студенти на освоєння та виконання практичних навичок витрачали більше часу порівняно 3 праворукими. Виявлена різниця в часі освоєння однієї практичної навички у відсотках у середньому дорівнювала $6,40 \pm 0,21 \%$, тобто, студенти 3 домінуванням лівої руки кожну практичну навичку виконували довше порівняно з праворукими.

Варто зазначити, що останнім часом сучасна педагогічна наука все частіше звертає увагу на особливості навчання, ефективність та якість засвоєння навчальних дисциплін праворукими та ліворукими студентами і учнями $[4,7,10]$. У даний час відомо, що психофізіологічні відмінності право- і ліворуких осіб зумовлені відмінностями функцій і домінуванням лівої та правої півкуль головного мозку. Так, ліва півкуля головного мозку, яка домінує в праворуких, відповідає за знакову інформацію (рахунок, читання, мови, ремесло), за здатність аналізувати предмети та явища (розкладати їх на окремі елементи і формувати логічні ланцюжки). Права півкуля мозку, яка домінує в ліворуких осіб, має тенденцію більше до узагальнення та синтезу, забезпечуючи цілісність сприйняття. Безумовно, що ліва та права півкулі головного мозку функціонують у тісному взаємозв'язку, проте відносне домінування правої чи лівої півкуль зумовлює не тільки тип мислення людини, а й визначає іiі характер, тем- перамент, тривожність, ступінь невротизації, швидкість мислення, пам'ять, здатність концентруватися та інші психофізіологічні особливості $[8,10,11]$. Слід також вказати, що особи з домінуванням лівої руки більш вразливі, збудливі, чутливі порівняно з праворукими, проте вони часто невпевнені в собі, схильні до різких змін настрою. Ліворукі в стресових ситуаціях нерідко схильні до песимізму та смутку. Для них характерна слабкість вольового контролю і контролю поведінки, їм нелегко стримувати свої емоції, у тому числі й агресивні.

Відомо, що в корі лівої нижньої тім'яної часточки головного мозку (більш точно - в gyrus supramarginalis) у праворуких локалізована частина рухового аналізатора, за участі якого здійснюються цільові та цілеспрямовані комбіновані рухи. Вважається, що в ліворуких осіб сигнал до здійснення цільових комбінованих рухів $є$ більш пролонгованим $[8,10]$.

На основі отриманих даних проведеного педагогічного експерименту та проаналізованих даних літератури можна дійти висновку, що ефективне засвоєння практичних навичок із нормальної фізіології залежить від психофізіологічних особливостей студента, тобто, домінування лівої або правої півкуль головного мозку. Студенти обстежуваних груп (право- і ліворукі) характеризуються не лише різними психофізіологічними особливостями, але й неоднаковим сприйняттям та засвоєнням навчальної інформації. Звідси випливає, що при прогнозуванні ефективності засвоєння практичних навичок необхідно враховувати психофізіологічні особливості студентів: право- та ліворукість. Деякі дослідники стверджують, що особам із домінуючою лівою рукою нелегко дається все те, що пов'язане з необхідністю швидкого перемикання з одного процесу на інший $[3,7,10]$, що необхідно враховувати при виконанні студентами практичних навичок.

При навчанні в ліворуких осіб тривалий час може спостерігатися дисграфія та дислексія, тобто, стійке порушення процесів читання, писання, виконання цілеспрямованих рухів, яке може нерідко повторюватися, що зумовлене неповноцінною сформованістю вищих психічних функцій, які беруть участь у наведених вище процесах $[9,11]$.

Отримані результати та аналіз літератури дозволяє стверджувати, що особам із домінуванням лівої руки або нестійкою матеріалізацією значно тяжче дається виконання практичних навичок порівняно з праворукими, що вимагає ін- 
дивідуальних підходів для повноцінного та ефективного засвоєння практичних навичок. Це свідчить, що при освоєнні та виконанні практичних навичок на практичних заняттях та відпрацюваннях потрібно більшу увагу зосереджувати на ліворуких студентах порівняно 3 праворукими. Наведене вище підтверджувалося також даними анонімного анкетування студентів.

\section{Висновок}

Для ліворуких та праворуких студентів характерні різні психофізіологічні особливості; вони неоднаково засвоюють необхідні практичні навички з нормальної фізіології. Для повноцінного та ефективного засвоєння практичних навичок із даного навчального предмета більше уваги потрібно приділяти студентам із домінуванням правої півкулі головного мозку.

Перспективи подальших досліджень. Подальше дослідження психофізіологічних особливостей студентів і врахування їх при виконанні та засвоєнні практичних навичок із нормальної фізіології допоможе більш повноцінно та ефективно опанувати їх.

\section{Література}

1. Альчук О.І. Формування професіональних компетенцій у майбутніх лікарів у системі новітніх технологій / О.І. Альчук, Н.І. Волощук, Л.Ф. Лозинська // Мед. освіта. - 2016. - № 1. - С. 5-7.

2. Гнатюк М.С. Особливості засвоєння студентами практичних навичок 3 оперативної хірургії та топографічної анатомії у ДВНЗ «Тернопільський державний медичний університет імені I.Я. Горбачевського» /
М.С. Гнатюк, Л.В. Татарчук, О.Б. Слабий: матеріали науково-практичної конференції ["Нові напрямки впровадження кредитно-модульної системи організації навчального процесу у вищих медичних і фармацевтичному закладах України III-IV рівня акредитації“] ( $12-13$ травня 2011 р.). - Тернопіль: Укрмедкнига, 2011. - C. 72-73.

3. Доброхотова Т.А. Нейропсихиатрия / Т.А. Доброхотова. - М.: БИНОМ, 2006. -304 с.

4. Имитационное обучение в системе непрерывного медицинского профессионального образования / под ред. П.В.Глыбочко. - М.: Издательство Первого МГМУ им. И.М.Сеченова, 2012. - 120 с.

5. Калашникова К.А. Проблеми формування практичних навичок на кафедрі пропедевтики педіатрії в умовах використання кредитно-модульної системи / К.А. Калашникова, О.О. Старець, Н.О. Нікітіна // Мед. освіта. - 2012. - № 4. - С. 53-55.

6. Маркина Н. Мозг правшей и левшей / Н. Маркина // Наука и жизнь. - 2016. - С. 72-74.

7. Светлов Р.С. Левши и правши / Р.С.Светлов. - М.: Педагогика-Пресс, 2011. - 43 с.

8. Семенович А.В. Эти невероятные левши / А.В. Семенович. - М.: Генезис, 2005. -250 с.

9. Чуприков А.П. Асиметрія мозку та ліворукість / А.П. Чуприков, Р.М. Гнатюк, М.А. Чуприкова. - К.: CMM, 2011. - $140 \mathrm{c}$.

10. Шимко И.А. Динамика лабильности церебральных УПП и психофизиологических параметров детей 10 11 лет с гетеротипной межполушарной асимметрией в условиях тренировки концентрации внимания / И.А .Шимко, О.А. Андреев // Асимметрия. - 2010. № 1. - C. 38-51.

11. Chuprikov A. Autism spectrum disorders. Medical, psychological and pedagogical support / A. Chuprikov, A. Hvorova. - Soarbrucken: Lambert Academic Publishing, 2013. $-324 \mathrm{p}$.

\section{ВЛИЯНИЕ ПСИХОФИЗИОЛОГИЧЕСКИХ ОСОБЕННОСТЕЙ СТУДЕНТОВ НА ОСВОЕНИЯ ПРАКТИЧЕСКИХ НАВЫКОВ ПО НОРМАЛЬНОЙ ФИЗИОЛОГИИ}

\section{Л.В. Татарчук, Р.М. Гнатюк, С.Н. Вадзюк}

Резюме. В работе показаны особенности освоения практических навыков студентами по нормальной физиологии в зависимости от психофизиологических состояний. Выявлено, что полноценное освоение практических навыков по нормальной физиологии зависит от доминирования левого или правого полушарий головного мозга, что требует индивидуальных подходов при их освоении и выполнении.

Ключевые слова: практические навыки, психофизиология, нормальная физиология

\section{THE INFLUENCE OF PSYCHOPHYSIOLOGICAL PECULIARITIES OF STUDENTS ON MASTERING PRACTICAL SKILLS ON NORMAL PHYSIOLOGY}

\section{L.V. Tatarchuk, R.M. Hnatiuk, S.N. Vadziuk}

Abstract. The paper shows the features of practical skills of students on normal physiology depending on their psychophysiological conditions. It was found that full-fledged mastering of practical skills on normal physiology depends on the dominance of the left or right hemispheres of the brain, requiring individual approaches in their development and implementation.

Key words: practical skills, psychophysiology, normal physiology

I.Ya. Horbachevskyi State Medical University (Ternopil) 